\title{
Analysis of Empowerment Program that was Implemented in Mamuju Regency East Sulawesi Indonesia
}

\author{
Umi Farida \\ Universitas Tomakaka \\ Mamuju, East Sulawesi, Indonesia \\ Bustamin \\ Universitas Tomakaka \\ Mamuju, East Sulawesi, Indonesia
}

\author{
Eko Wagiyanto \\ Universitas Negeri Makassar \\ Makassar, Indonesia \\ Rudi Salam \\ Universitas Negeri Makassar \\ Makassar, Indonesia
}

\begin{abstract}
Community Development National Program is one of empowerment policy in Indonesia. One strategy of the policy is health and education. The purpose of this study is to evaluate the implementation of the National Program for Community Empowerment, especially in Healthy and Education Mamuju. This research is a qualitative descriptive which aims to obtain a clear picture of the policy implementation in Mamuju. Data collection techniques in research using interview, observation and documentation. The researcher using the interactive model technique in data analysis. The results of this study indicated that the program already could be quite good such as; 1) Local authorities, district and village levels as offender conducted communication by transparent, open, and consistent. However, the beneficiaries did not really understand the details of the program itself. 2) Human resources, information, and finance for program implementation was adequate. However, the facilities were still inadequate 3) Disposition between the parties involved was good enough 4) the bureaucratic structure of the program has been running well and in accordance with the operational standard as well as responsibilities.
\end{abstract}

\section{Keywords- policy, implementation, empowerment program}

\section{INTRODUCTION}

Community empowerment as a development paradigm in Indonesia to develop the intellectual aspects of human resources, material aspects, the physical aspect and managerial aspects. [1]. National Community Empowerment Program is a community empowerment mechanism to accelerate poverty reduction and expansion of employment opportunities in rural areas. Moreover, West Sulawesi as a new province in South Sulawesi running the National Program for Community Empowerment (PNPM) Healthy and Smart Generation (GSC). This program is a national program in the framework of a special poverty alleviation in the areas of education and health. The program refers to the foundations of empowerment by integrating aspects of awareness, capacity and utilization. PNPM GSC involve the community in the stages of planning, implementation and evaluation of programs [2].

Policy implementation is a process that leads to the implementation of a policy [3]. Policies can be in the form of laws, decisions of the executive or judicial decision. Policies identify the problems it seeks to alleviate, explicitly mention goals or objectives to be achieved, and various ways to structure or organize the implementation process. [4]-[5]. In the process of public policy, policy implementation is the link between policy formulation with the results (outcomes) policy is expected.

There are four aspects that need to be assessed in policy implementation, namely: 1) who is implementing, 2) the nature of the administrative process, 3 ) compliance, and 4) the impact of the implementation of the policy. Furthermore, the elements of public policy implementation is the Executor (implementer), the program and the target group (target group) [6]. In theory policy, there are four factors or variables that influence each other. These variables include: communication, resources, disposition and bureaucratic structure [7]. The purpose of this study see how the Implementation of the National Program for Community Empowerment (PNPM) Healthy and Smart Generation (GSC) in Mamuju.

\section{METHOD}

This type of research is qualitative descriptive research. The subjects in this study are stakeholders in the implementation of policies as much as twelve [8]. The location of the research was conducted in Kabupaten Mamuju. The subjects in this study are district level executives, district level actors, group targets, local district actors. The focus of the study consists of a variable communication, resources, disposition and structure bureaucracy [9]. Namely data collection techniques with in-depth interviews.

\section{III.RESULTS}

Implementation of National Program for Community Empowerment (PNPM) Healthy and Smart Generation in Mamuju visits based policy model Implementation by [10] composed of four variables. Therefore, the variables that determine the success public implementation as follows:

\section{A. Communication}

Communication is the process of transforming a policy that not only do the perpetrators of the policy, but also on the target group [11]-[13]. Communication is done by implementing the National Program for Community Empowerment (PNPM) Healthy and Smart Generation in Mamuju is through dissemination to the public. The number of actors in Mamuju district there are 12 actors. 
. Empowerment (PNPM) Healthy and Smart Generation is started from the selection of the target chosen randomly. Where the village government should make a statement of willingness to participate in the program and are willing to run the program in relation with applicable regulations. Socialization begins with workshops conducted at the office of Regent Mamuju. The aim of workshop is to maximize synergy in every process stage activity in PNPM-GSC start from the district level down at the level of village. The implementation of PNPM Generasi in Kabupaten Mamuju understands how to address health and education issues for the community itself. Addressing such problems village executors hold village meetings with citizens and community leaders to discuss together to find common solutions.

\section{B. Resources}

The resource element becomes one of the most important factors in the successful implementation of the policy. Without adequate resources, policy implementation will have difficulties, according to [14] Indicators used to look at the extent to which resources affect the implementation of policies are staff, information, authority and facilities.

One resource that plays an important role in this program is a human resources (staff) [15]-[17]. In the implementation of the PNPM-GSC particularly in Mamuju and many actors took on the task that is in conformity with their respective workloads. The program implementation or the executor always coordinate well with educational institutions and health by visiting a number of schools and neighborhood health center to visit the beneficiaries of the program. This is in order to determine the extent of the National Program for Community Empowerment (PNPM) Healthy and Smart Generation walk.

Other indicator in resources is the facility. Where facilities used in the implementation of the National Program for Community Empowerment (PNPM) Healthy and Smart Generation in Mamuju district has been very supportive. This is due to the availability of computer equipment to support the performance of the perpetrators of the program to carry out their duties. In PNPM- GC, the supproting facilities are service area (posyandu) is riding in the houses of citizens. The early childhood facilities in several villages in Mamuju district has built 44 health centers, village health setvice as much 23 and 6 women as midwife.

\section{Disposition}

Disposition variables include attitude, behavior, commitment and incentive program [18], [19]. Based on the information in the field actors always are friendly program and do not want to receive any compensation from any beneficiary communities. The people feel happy and satisfied with the attitude and behavior of the perpetrators. The Ministry of Health and The Ministry of Education workers also being kind and friendly for accept-ing complaints from the public beneficiaries of the National Program for Community Empowerment (PNPM) Healthy and Smart Generation. Without good attitudes and behavior and high dedication from the implementers of the Healthy and Smart Generation National Community Empowerment Program (PNPM), it will be felt that health service providers, educators and program beneficiaries will receive information.

Based on the information in the field, the perpetrators of the program are always friendly and do not want to receive any rewards from the community so that the beneficiaries are happy and satisfied with the attitude and behavior of the program actors in Mamuju Regency. The ministry of health and education workers also being kind and friendly for accepting complaints from the public beneficiaries of the National Program for Community Empowerment (PNPM) Healthy and Smart Generation. Besides actors and personnel from the health and education services should also have a good commitment that the National Program for Community Empowerment (PNPM) Healthy and Smart Generation can run properly in accordance with the objectives set. To get an implementer who has a good attitude or good behavior and high dedication, then the citizens must also choose a good candidate and can also be trusted.

\section{Bureaucratic structure}

Procedure Operational Standard (SOP) is a routine activity which allows implementers [20], [21]. While fragmentation is the responsibility of each staff. Levels of bureaucracy involved in this program must be clear because it will affect the success of the poverty alleviation program.

The establishment of a team of management and organization at the provincial, district, sub-district and village shows the lack of seriousness in implementing the program in relation with the prescribed rules. In addition to the standard, the bureaucratic structure in Mamuju can be seen from the authority of the actors in the distribution program or perform tasks, roles and functions as well as the spread of the responsibility of implementing the program. Their duties and responsibilities are in accordance with the instructions set out in the technical operation in which the generation PNPM these instructions will help implement this program so well that it does not need a long bureaucratic ladder. In addition to SOP, the bureaucratic structure in Mamuju Regency can act as the dissemination of the responsibilities of the program implementers. The duties and responsibilities are in line with those set forth in the PNPM technical operational guidelines of the generation where so long it does not need long bureaucratic levels.

Implementation of the National Program for Community Empowerment (PNPM) Generation of Healthy and Smart in Mamuju are in accordance with the duties and responsibilities, namely to collect data on the poor in particular for pregnant mothers with children under five and children of primary school age and junior. All duties and responsibilities remain under the supervision of the head of the village. This is to avoid going any irregularities and misappropriation.

\section{CONCLUSION}

The result of research are communication in the implementation of policy is transparent, open and consistent. Communications is done between the perpetrator and the target is less understood by beneficiaries. The possible beneficiaries of education level is still low so that the mindset of beneficiaries still low. They do not understand the details of the assistance from the program itself. Resources of policy implementation are sufficient, covering human resources or staff, information resources and financial resources. Power source equipment or facilities already support the performance and duties of the perpetrators in the village for their facility such as a computer. Disposition of the form of 

care and education has shown a good attitude and also has a

[21] M. Kirchmer, Business process oriented implementation of standard software: how to achieve competitive advantage efficiently and effectively. Springer Science \& Business Media, 2012.

high commitment in carrying out their duties properly, even though the actors working voluntarily without any remuneration / salary monthly. The bureaucratic structure, the implementation of policy is in accordance with the standard. Executing of policy implementation already carry out their duties properly and in accordance with the rules that have been set. Fragmentation or responsibilities are deposited in the form of a report at the end of that documentation SPPB and also proposals for submission in the next year budget.

\section{REFERENCES}

[1] S. K. Farnsworth et al., "Community engagement to enhance child survival and early development in low-and middle-income countries: An evidence review," J. Health Commun., vol. 19, no. sup1, pp. 67-88, 2014.

[2] J. F. McCarthy et al., "10 Dilemmas of participation: the National Community Empowerment Program," Reg. Dyn. a Decentralized Indones., vol. 501, p. 233, 2014.

[3] S. Saggaf, R. Salam, F. Kahar, and H. Akib, "Pelayanan Fungsi Administrasi Perkantoran Modern," J. Ad'ministrare, vol. 1, no. 1, pp. 20-27, 2014.

[4] P. Sabatier and D. Mazmanian, "The implementation of public policy: A framework of analysis," Policy Stud. J., vol. 8, no. 4, pp. 538-560, 1980.

[5] M. S. Grindle, Politics and policy implementation in the Third World. Princeton University Press, 2017.

[6] M. Nur, A. Y. A. Gani, and M. S. Soeaidy, "Obstacles of Policy Implementation of Street Vendors Arrangement in Makassar, South Sulawesi, Indonesia," Int. J. Appl. Sociol., vol. 4, no. 1, pp. 30-33, 2014.

[7] G. C. Edwards III and S. J. Wayne, Presidential leadership: Politics and policy making. Cengage Learning, 2013.

[8] R. Salam, Rosdiana, Suarlin, and H. Akib, "The Impact of Policy on Region Expansion to Office Administrative Services in Barombong Substrict of Gowa District," in International Conference on Mathematics, Science, Technology, Education and their Applications (ICMSTEA) 2014, 2014.

[9] M. B. Miles, A. M. Huberman, and J. Saldana, Qualitative Data Analysis: A Methods Sourcebook, 3rd ed. United States of America: Sage Publications, 2014.

[10] G. C. Edward III, Implementing Public Policy. Washington, DC: Congressional Quarterly Press, 1980.

[11] A. Bandura, "Social cognitive theory of mass communication," Media Psychol., vol. 3, no. 3, pp. 265-299, 2001.

[12] B. S. Frey and S. Luechinger, "How to fight terrorism: alternatives to deterrence," Def. Peace Econ., vol. 14, no. 4, pp. 237-249, 2003.

[13] R. L. Nabi, "Exploring the framing effects of emotion: do discrete emotions differentially influence information accessibility, information seeking, and policy preference?," Communic. Res., vol. 30, no. 2, pp. 224-247, 2003

[14] L. Agustino, "Dasar-Dasar Kebijakan Publik, Bandung: CV," ALVABETA BANDUNG, 2008.

[15] J. Conner and D. Ulrich, "Human resource roles: Creating value, not rhetoric," People Strateg., vol. 19, no. 3, p. 38, 1996.

[16] P. M. Wright, G. C. McMahan, and A. McWilliams, "Human resources and sustained competitive advantage: a resource-based perspective," Int. J. Hum. Resour. Manag., vol. 5, no. 2, pp. 301-326, 1994.

[17] J. B. Barney and P. M. Wright, "On becoming a strategic partner: The role of human resources in gaining competitive advantage," Hum. Resour. Manag., vol. 37, no. 1, p. 31, 1998.

[18] R. M. Baron and D. A. Kenny, "The moderator-mediator variable distinction in social psychological research: conceptual, strategic, and statistical considerations.," J. Pers. Soc. Psychol., vol. 51, no. 6, pp. 1173-1182, 1986.

[19] P. C. Stern, "New environmental theories: toward a coherent theory of environmentally significant behavior," J. Soc. Issues, vol. 56, no. 3, pp. 407-424, 2000.

[20] A. C. Edmondson, R. M. Bohmer, and G. P. Pisano, "Disrupted routines: Team learning and new technology implementation in hospitals," Adm. Sci. Q., vol. 46, no. 4, pp. 685-716, 2001. 